\title{
PENILAIAN SISWA TERHADAP PENERIMAAN MATERI AJAR MATEMATIKA MENGGUNAKAN METODE MAMDANI: STUDI KASUS SMP CITRA DHARMA
}

\author{
Meri Chrismes Aruan \\ Program Studi Teknik Informatika, Universitas Indraprasta PGRI \\ Email: Meriprincess08aruan@gmail.com
}

\begin{abstract}
Abstrak
Pendidikan adalah tanggung jawab pemerintah, orangtua, dan masyarakat. Dimana sekolah sebagai lembaga formal yang berfungsi dan bertanggung jawab mengembangkan dan mempersiapkan generasi muda yang berkualitas, mandiri, dan mampu membangun bangsa di masa yang akan datang. Penilaian siswa terhadap pemahaman materi Matematika, ditentukan berdasarkan silabus pengajaran Matematika antara lain pemahaman tentang memahami kesebangunan bangun datar dan penggunaannya dalam pemecahan masalah. Dengan tercapainya nilai yang bagus dalam proses pembelajaran, menunjukan pembelajaran dilaksanakan secara berkualitas.Di SMP Citra Dharma,evaluasi penilaian siswa terhadap penerimaan materi Matematika masih menggunakan sistem manual hingga memakan waktu yanglama dan dapat berdampak pada hasil yang kurang akurat. Untuk itu perlu di buat model penilaian siswa terhadap penerimaan materi Matematika berbasis komputer (soft computing) menggunakan program Matlab R2012b dengan menggunakan metode Fuzzy Inference System (FIS) Mamdani.
\end{abstract}

Kata Kunci: Pendidikan, Matematika, Fuzzy Inference System(FIS) Mamdani, Matlab, prototype.

\section{Pendahuluan}

Pendidikan adalah tanggung jawab pemerintah, orangtua, dan masyarakat. Dimana sekolah sebagai lembaga formal yang berfungsi dan bertanggung jawab mengembangkan dan mempersiapkan generasi muda yang berkualitas, mandiri, dan mampu membangun bangsa di masa yang akan datang.

Proses kegiatan belajar mengajar harus dilakukan secara berkualitas agar tercapainya kepuasan siswa dalam menerima materi yang diberikan. Pendidikan dikatakan berkualitas bila proses belajar mengajar dapat berjalan dengan lancar, efektif, efisien, dan ada interaksi antara komponen-komponen yang terkandung dalam sistem pengajaran yaitu tujuan pendidikan dan pengajaran, peserta didik, tenaga pendidik, kurikulum, strategi pembelajaran, media pengajaran dan evaluasi pengajaran (Hamalik, 2005).

Untuk mengetahui kepuasan siswa maka diperlukan adanya evaluasi tentang penilaian siswa terhadap penerimaan materi ajar MATEMATIKA. Evaluasi adalah serangkaian kegiatan yang ditujukan untuk mengukur keberhasilan program pendidikan. Sedangkan penilaian adalah suatu usaha yang dilakukan dalam pengambilan keputusan terhadap sesuatu dengan ukuran baik buruk (Suharsimi, 2007). Keberhasilan siswa dapat dilihat dari prestasi yang dicapainya. Nilai prestasi dieskpresikan tidak saja secara numeris, tetapi juga dipresentasikan dalam bentuk kualitatif secara linguistik.

Berdasarkan hal tersebut, maka diperlukan sebuah model penilaian siswa terhadap penerimaan materi ajar MATEMATIKA Kelas IX di SMP Citra Dharma dengan menggunakan metode logika fuzzy mamdani agar penilaian siswa tersebut lebih efektif dan efesien. 


\section{Tinjauan Pustaka}

\section{Prototyping}

Prototyping merupakan salah satu metode pengembangan perangat lunak yang banyak digunakan. Dengan metode prototyping ini, developer dan client dapat saling berinteraksi selama proses pembuatan sistem. Sering terjadi seorang clienthanya mendefinisikan secara umum apa yang dikehendakinya tanpa menyebutkan secara detail output apa saja yang dibutuhkan, pemrosesan dan data-data apa saja yang dibutuhkan.

\section{Hakikat Matematika}

Menyatakan matematika terbentuk sebagai hasil pemkiran manusia yang berhubungan dengan ide, proses dan penalaran (Ruseffendi, 2006). Teori Bruner yang menyatakan belajar matematika akan lebih berhasil jika proses pengajaran yang diarahkan kepada konsep-konsep dan struktur-struktur dalam pokok bahasan tersebut. Teori Brownel matemtika merupakan belajar bermakna dan pengertian.

\section{Logika Fuzzy}

Logika Fuzzy pertama kali dikemukakan oleh Lotfi A Zadeh, seorang berkebangsaan Iran yang menjadi guru besar di University of California at Berkeley. Logika Fuzzy merupakan pengetahuan yang memiliki kemampuan untuk menjembatani bahasa mesin yang serba terukur dengan bahasa manusia yang cenderung tidak terukur. Misalnya saja ba hasa manusiau ntuk suhu udara (panas, sedang, dingin), panjang badan seseorang (tinggi, sedang, pendek), umur manusia (muda, tua, paruh baya), sampai pada penilaian terhadap pekerjaan (baik, sedang, jelek). Logika Fuzzy merupakan suatu cara yang tepat untuk memetakan suatu ruang input kedalam suatu ruang output.

Ada beberapa alasan mengapa logika fuzzy digunakan, antara lain $($ Cox, 1994) :

1. Konsep Logika Fuzzy mudah dipahami.

2. Logika Fuzzy sangat fleksibel

3. Logika Fuzzy memiliki toleransi terhadap data yang tidak tepat

4. Logika Fuzzy mampu memodelkan fungsi-fungsi nonlinier yang sangat kompleks

\section{Logika Fuzzy Mamdani}

Metode Mamdani sering dikenal dengan nama metode max-min. Untuk mendapatkan output dari metode ini, langkah yang harus dilakukan adalah sebagai berikut:

1. Pembentukan himpunan fuzzy

Pada tahap ini, baik variabel input maupun output dibagi menjadi satu atau lebih himpunan fuzzy.

2. Aplikasi fungsi implikasi (aturan)

Fungsi implikasi yang digunakan adalah min

3. Komposisi aturan

4. Penegasan (defuzzy)

Input dari proses defuzzifikasi adalah suatu himpunan fuzzy yang diperoleh dari komposisi aturanaturan fuzzy, sedangkan output yang dihasilkan merupakan suatu bilangan pada domain himpunan fuzzy tersebut. Sehingga jika diberikan suatu himpunan fuzzy dalam range tertentu, maka harus dapatdiambil suatu nilai crisp tertentu sebagai output.

\section{Jaminan Kualitas Perangkat Lunak (Software Quality Assurance)}

Software Quality Assurance (SQA) bertujuan untuk menghasilkan suatu produk software berkualitas tinggi. SQA merupakan salah satu kegiatan yang harus dilakukan dalam suatu proses pengembangan perangkat lunak.

Pentingnya pelaksanaan SQA pada dasarnya adalah untuk menekan biaya dan menjaga ketepatan waktu selesainya pengembangan perangkat lunak. Jika pengembangan software menekankan pentingnya kualitas perangkat lunak pada semua aktivitas pengembangan software, maka pada dasarnya hal ini akan mengurangi jumlah pekerjaan ulang yang harus dilakukan (Pressman, 2010). Tentu saja hasilnya adalah penggunaan biaya yang rendah dan ketepatan waktu.

Matlab R2012b 
MATLAB adalah singkatan dari MATrix LABoratory. Pertama kali dibuat pada tahun 1970 untuk mempermudah penggunaan dua koleksi subrutin pada pustaka FORTRAN yaitu: LINPACK dan EISPACK, dalam menangani komputasi matriks.

Matlab adalah bahasa pemrograman tingkat tinggi dimana arti perintah dan fungsifungsinya bisa dimengerti dengan mudah, meskipun bagi seorang pemula. Hal itu karena di dalam matlab, masalah dan solusi bisa di ekspresikan dalam notasi-notasi matematis yang biasa (Agus Saba, 2009).

\section{Metodologi Penelitian}

Penelitian ini dilakukan untuk mengetahui kepuasan siswa terhadap penerimaan materi ajar Matematika dengan menggunakan Fuzzy Inference System (FIS) Mamdani.Untuk mendapatkan informasi yang dibutuhkan dari objek yang akan diteliti oleh karena itu dilakukan pengamatan langsung di SMP Citra Dharma.

1. Penelitian pendahuluan

Penelitian ini dilakukan untuk memperoleh kriteria-kriteria dalam penelitian, Kriteria yang dibuat berdasarkan silabus khususnya mata pelajaran Matematika. Kriteria ini untuk menentukan tingkat kepuasan siswa terhadap penerimaan materi ajar Matematika kemudian dibuat kuisionernya dan disebarkan kepada siswa.

2. Kuisioner

Setelah memperoeh kriteria-kriteria dari penelitian pendahuluan selanjutnya akan dibuat kuisioner penelitian.

3. Mengelola hasil kuisioner

Data yang diperoleh dari kuisioner kemudian dimasukkan sebagai input, sedangkan output kepuasan siswa adalah kurang, cukup, dan baik dengan menggunakan pendekatan logika fuzzy dengan tool matlab R2012b.

\section{Hasil dan Pembahasan}

\section{Analisis Masalah}

1. Perancangan yang dibuat dengan menggunakan penalaran fuzzy dengan menggunakan metode Mamdani.

2. Pembuatan aturan dalam basis pengetahuan dibantu oleh kepala sekolah dan guru Matematika.

Tabel 1. Dekomposisi Variabel Model Menjadi Himpunan Fuzzy yang Digunakan

\begin{tabular}{clc}
\hline \multirow{2}{*}{ Fungsi } & \multicolumn{1}{c}{ Variabel } & $\begin{array}{c}\text { Semesta } \\
\text { Pembicaraan } \\
\text { (Nilai/Range) }\end{array}$ \\
\hline \multirow{2}{*}{ 2 Input } & Menuliskan sifat-sifat dua bangun datar yang sebangun dan kongruen & {$[0-10]$} \\
& Mengidentifikasi dua bangun datar sebangun dan yang kongruen & {$[0-10]$} \\
\hline 1 Output & Skor Bangun-bangun sebangun dan kongruen & {$[\mathbf{0}-\mathbf{1 0}]$} \\
\hline \multirow{2}{*}{ 2 Input } & Menuliskan sifat-sifat dua segitiga yang sebangun dan kongruen & {$[0-10]$} \\
& Memecahkan masalah sehari-hari yang terkait dengan segitiga-segitiga. & {$[0-10]$} \\
\hline 1 Output & Skor Segitiga-segitiga Sebangun & {$[\mathbf{0 - 1 0}]$} \\
\hline \multirow{2}{*}{ Input } & Menterjemahkan masalah sehari-hari dalam konsep segitiga sebangun & {$[0-10]$} \\
\hline 1 Output & Memecahkan masalah sehari-hari yang terkait dengan segitaga-setiga sebangun & {$[0-10]$} \\
\hline
\end{tabular}

\section{Membentuk Himpunan Fuzzy}

Tabel 2. Tabel Himpunan fuzzy

\begin{tabular}{lcc}
\hline \multicolumn{1}{c}{ Variabel } & Himpunan Fuzzy & Domain \\
\hline Menuliskan sifat-sifat dua bangun datar & Kurang & {$[0,5]$} \\
yang sebangun dan kongruen. & Cukup & {$[4,8]$} \\
& Baik & {$[7,10]$} \\
\hline
\end{tabular}




\begin{tabular}{lcc}
\hline Mengidentifikasi dua bangun datar & Kurang & {$[0,5]$} \\
sebangun dan yang kongruen & Cukup & {$[4,8]$} \\
& Baik & {$[7,10]$} \\
\hline \multirow{2}{*}{$\begin{array}{l}\text { Menuliskan sifat-sifat dua segitiga yang } \\
\text { sebangun dan kongruen }\end{array}$} & Kurang & {$[0,5]$} \\
& Cukup & {$[4,8]$} \\
Memecahkan masalah sehari-hari yang & Baik & {$[7,10]$} \\
terkait dengan segitiga-segitiga & Kurang & {$[0,5]$} \\
sebangun & Cukup & {$[4,8]$} \\
\hline \multirow{2}{*}{$\begin{array}{l}\text { Menterjemahkan masalah sehari-hari } \\
\text { dalam konsep segitiga sebangun. }\end{array}$} & Baik & {$[7,10]$} \\
& Kurang & {$[0,5]$} \\
Memecahkan masalah sehari-hari yang & Cukup & {$[4,8]$} \\
terkait dengan segitiga-segitiga & Baik & {$[7,10]$} \\
sebangun. & Kurang & {$[0,5]$} \\
& Cukup & {$[4,8]$} \\
\hline
\end{tabular}

Terdapat 6 indikator yang akan dianalisis dan dijadikan variabel untuk menentukan penilaian siswa terhadap penerimaan materi ajar Matematika.

\section{Variabel Menuliskan Sifat-sifat Dua Bangun Datar yang Sebangun}

Pada variabel pengoperasian berbasis teks didefinisikan tiga himpunan fuzzy, yaitu Kurang, Cukup dan Baik. Himpunan fuzzy Kurang akan memiliki domain [0,5] dimana derajat keanggotaan Kurang tertinggi $(=1)$ terletak pada angka 0-4. Himpunan fuzzy Cukup memiliki domain $[4,8]$ dimana derajat keanggotaan Cukup tertinggi $(=1)$ terletak pada nilai 6. Himpunan fuzzy Baik akan memiliki domain $[7,10]$ dimana derajat keanggotaan Baik tertinggi $(=1)$ terletak pada angka $\geq 8$. Variabel menuliskan sifat-sifat dua bangun datar yang sebangun dapat dipresentasikan dengan fungsi keanggotaan bahu dan segitiga dengan gambar dibawah ini :

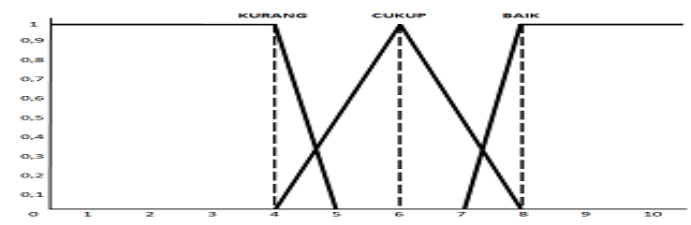

\section{Gambar 1. Himpunan Fuzzy untuk Variabel Sifat-sifat Dua Bangun Datar yang Sebangun}

Persamaan :

$$
\begin{aligned}
& \mu \operatorname{Kurang}[x]=\left\{\begin{array}{lr}
1 & ; 0 \leq x \leq 4 \\
(5-x) /(5-4) ; & 4 \leq x \leq 5 \\
0 ; & x \geq 5
\end{array}\right. \\
& \mu \operatorname{CUKUP}[x]= \begin{cases}(x-4) /(6-4) ; & 4 \leq x \leq 6 \\
(8-x) /(8-6) ; & 6 \leq x \leq 8 \\
0 & ; x \leq 4 \text { ataux } \geq 8\end{cases} \\
& \mu \text { BAIK }[x]= \begin{cases}0 & x \leq 7 \\
(x-7) /(8-7) ; & 7 \leq x \leq 8 \\
1 & ; 8 \leq x \leq 10\end{cases}
\end{aligned}
$$

\section{Variabel Mengidentifikasi Dua Bangun Datar Sebangun dan yang Kongruen}

Pada variabel Perangkat Jaringan didefinisikan tiga himpunan fuzzy, yaitu Kurang, Cukup dan Baik. Himpunan fuzzy Kurang akan memiliki domain [0,5] dimana derajat keanggotaan Kurang tertinggi $(=1)$ terletak pada angka 0-4. Himpunan fuzzy Cukup memiliki domain $[4,8]$ dimana derajat keanggotaan Cukup tertinggi $(=1)$ terletak pada nilai 6 . Himpunan fuzzy Baik akan memiliki domain [7,10] dimana derajat keanggotaan Baik tertinggi $(=1)$ terletak 
pada angka $\geq 8$. Variabel mengidentifikasi dua bangun datar sebangun dan yang kongruen dengan fungsi keanggotaan bahu dan segitiga dengan gambar dibawah ini :

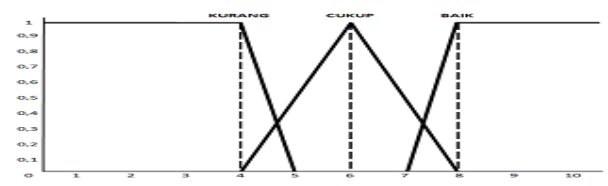

Gambar 2. Himpunan Fuzzy untuk Variabel Mengidentifikasi DuaBangun Datar Sebangun dan yang Kongruen

Dengan persamaan :

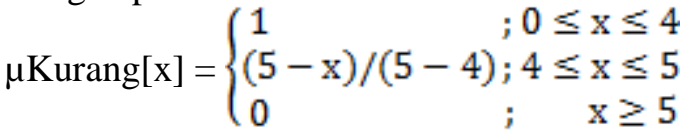

$\mu \operatorname{CUKUP}[x]= \begin{cases}(x-4) /(6-4) ; & 4 \leq x \leq 6 \\ (8-x) /(8-6) ; & 6 \leq x \leq 8 \\ 0 & ; x \leq 4 \text { ataux } \geq 8\end{cases}$

$\mu$ BAIK $[x]= \begin{cases}0 & ; x \leq 7 \\ (x-7) /(8-7) ; & 7 \leq x \leq 8 \\ 1 & ; 8 \leq x \leq 10\end{cases}$

3. Variabel Menuliskan Sifat-sifat Dua Segitiga yang Sebangun dan Kongruen

Pada variabel Utilitas Koneksi didefinisikan tiga himpunan fuzzy, yaitu Kurang, Cukup dan Baik. Himpunan fuzzy Kurang akan memiliki domain [0,5] dimana derajat keanggotaan Kurang tertinggi $(=1)$ terletak pada angka 0-4. Himpunan fuzzy Cukup memiliki domain $[4,8]$ dimana derajat keanggotaan Cukup tertinggi $(=1)$ terletak pada nilai 6 . Himpunan fuzzy Baik akan memiliki domain [7,10] dimana derajat keanggotaan Baik tertinggi $(=1)$ terletak pada angka $\geq 8$. Variabel menuliskan sifat-sifat dua segitiga yang sebangun dan kongruen dengan fungsi keanggotaan bahu dan segitiga dengan gambar dibawah ini :

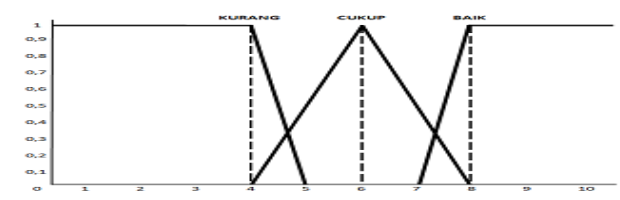

Gambar 3. Himpunan fuzzy untuk Variabel Menuliskan Sifat-sifat Dua segitiga yang Sebangun dan Kongruen

Dengan persamaan :

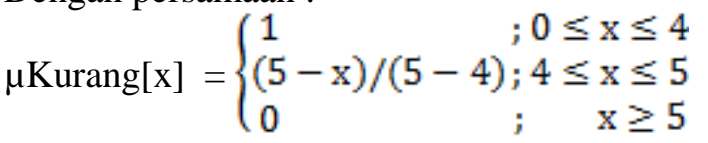

$$
\begin{aligned}
& \mu \operatorname{CUKUP}[x]= \begin{cases}(x-4) /(6-4) & ; 4 \leq x \leq 6 \\
(8-x) /(8-6) & ; 6 \leq x \leq 8 \\
0 & ; x \leq 4 \text { ataux } \geq 8\end{cases} \\
& \mu \text { BAIK }[x]= \begin{cases}0 & ; x \leq 7 \\
(x-7) /(8-7) ; & 7 \leq x \leq 8 \\
1 & ; 8 \leq x \leq 10\end{cases}
\end{aligned}
$$

4. Variabel Memecahkan Masalah dengan Segitiga-segitiga Sebangun

Pada variabel memecahkan masalah dengan segitiga-segitiga sebangun didefinisikan tiga himpunan fuzzy, yaitu Kurang, Cukup dan Baik. Himpunan fuzzy Kurang akan memiliki domain $[0,5]$ dimana derajat keanggotaan Kurang tertinggi $(=1)$ terletak pada angka 0-4. 
Himpunan fuzzy Cukup memiliki domain [4,8] dimana derajat keanggotaan Cukup tertinggi $(=1)$ terletak pada nilai 6 . Himpunan fuzzy Baik akan memiliki domain $[7,10]$ dimana derajat keanggotaan Baik tertinggi $(=1)$ terletak pada angka $\geq 8$. Variabel memecahkan masalah dengan segitiga-segitiga sebangun dipresentasikan dengan fungsi keanggotaan bahu dan segitiga dengan gambar dibawah ini :

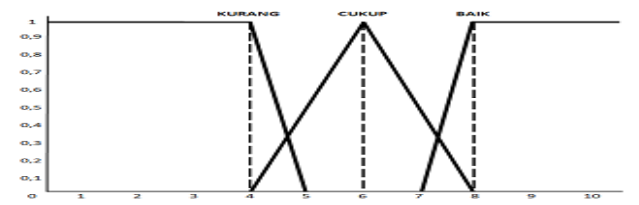

\section{Gambar 4.Himpunan Fuzzy untuk Variabel Memecahkan masalah dengan} Segitiga-segitiga Sebangun

Dengan persamaan :

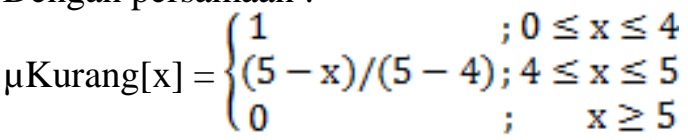

$$
\begin{aligned}
& \mu \operatorname{CUKUP}[x]= \begin{cases}(x-4) /(6-4) ; 4 \leq x \leq 6 \\
(8-x) /(8-6) ; 6 \leq x \leq 8 \\
0 & ; x \leq 4 \text { ataux } \geq 8\end{cases} \\
& \mu \text { BAIK }[x]= \begin{cases}0 & ; x \leq 7 \\
(x-7) /(8-7) ; & 7 \leq x \leq 8 \\
1 & ; 8 \leq x \leq 10\end{cases}
\end{aligned}
$$

5. Variabel Menterjemahkan Masalah Sehari-hari dalam Konsep Segitiga Sebangun Pada variabel menterjemahkan masalah sehari-hari dalam konsep segitiga sebangun didefinisikan tiga himpunan fuzzy, yaitu Kurang, Cukup dan Baik. Himpunan fuzzy Kurang akan memiliki domain [0,5] dimana derajat keanggotaan Kurang tertinggi $(=1)$ terletak pada angka 0-4. Himpunan fuzzy Cukup memiliki domain [4,8] dimana derajat keanggotaan Cukup tertinggi $(=1)$ terletak pada nilai 6 . Himpunan fuzzy Baik akan memiliki domain $[7,10]$ dimana derajat keanggotaan Baik tertinggi $(=1)$ terletak pada angka $\geq 8$. Variabel menterjemahkan masalah sehari-hari dalam konsep segitiga sebangun dipresentasikan dengan fungsi keanggotaan bahu dan segitiga dengan gambar dibawah ini :

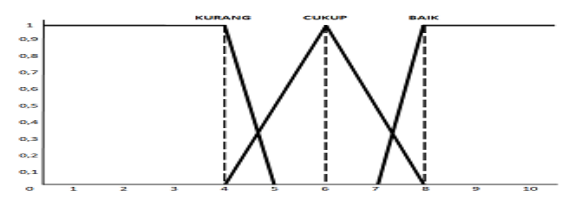

Gambar 5. Himpunan Fuzzy untuk Variabel Menterjemahkan Masalah Seharihari dalam Konsep Segitiga Sebangun

Dengan persamaan :

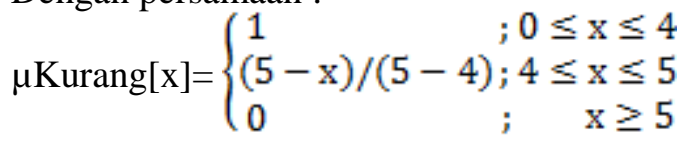

$$
\begin{aligned}
& \mu \operatorname{CUKUP}[x]= \begin{cases}(x-4) /(6-4) ; & 4 \leq x \leq 6 \\
(8-x) /(8-6) ; & 6 \leq x \leq 8 \\
0 & ; x \leq 4 \text { ataux } \geq 8\end{cases}
\end{aligned}
$$


$\mu$ BAIK $[x]= \begin{cases}0 & ; x \leq 7 \\ (x-7) /(8-7) ; & 7 \leq x \leq 8 \\ 1 & ; 8 \leq x \leq 10\end{cases}$

6. Variabel Memecahkan Masalah Sehari-hari yang Terkait dengan Segitiga-segitiga Sebangun Pada variabel memecahkan masalah sehari-hari yang terkait dengan segitiga-segitiga sebangun didefinisikan tiga himpunan fuzzy, yaitu Kurang, Cukup dan Baik. Himpunan fuzzy Kurang akan memiliki domain [0,5] dimana derajat keanggotaan Kurang tertinggi $(=1)$ terletak pada angka 0-4. Himpunan fuzzy Cukup memiliki domain [4,8] dimana derajat keanggotaan Cukup tertinggi $(=1)$ terletak pada nilai 6. Himpunan fuzzy Baik akan memiliki domain [7,10] dimana derajat keanggotaan Baik tertinggi $(=1)$ terletak pada angka $\geq 8$. Variabel memecahkan masalah sehari-hari yang terkait dengan segitiga-segitiga sebangun dipresentasikan dengan fungsi keanggotaan bahu dan segitiga dengan gambar dibawah ini :

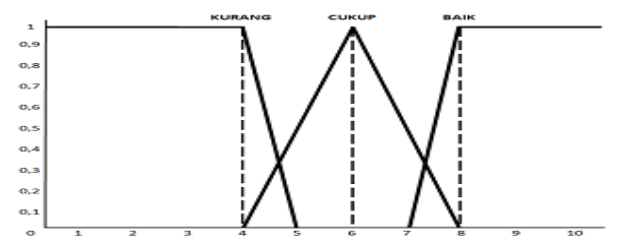

Gambar 6. Himpunan fuzzy untuk Variabel Memecahkan masalah sehari-hari yang terkait dengan segitiga-segitiga sebangun

Dengan persamaan :

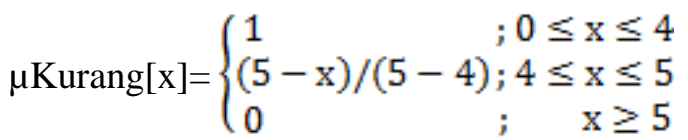

$\mu \operatorname{CUKUP}[x]= \begin{cases}(x-4) /(6-4) ; & 4 \leq x \leq 6 \\ (8-x) /(8-6) ; & 6 \leq x \leq 8 \\ 0 & ; x \leq 4 \text { ataux } \geq 8\end{cases}$

$\mu$ BAIK $[x]=\left\{\begin{array}{llc}0 & ; & x \leq 7 \\ (x-7) /(8-7) ; & 7 \leq x \leq 8 \\ 1 & ; & 8 \leq x \leq 10\end{array}\right.$

\section{Hasil Penelitian}

Kuesioner Penilaian yang diisi oleh siswa dan siswi SMP Citra Dharma untuk evaluator sebanyak 40 siswa dengan jumlah kuesioner 1 lembar. Himpunan Fuzzy 3 variabel 1 Output Mamdani.

a. Bangun-bangun yang sebangun dan kongruen

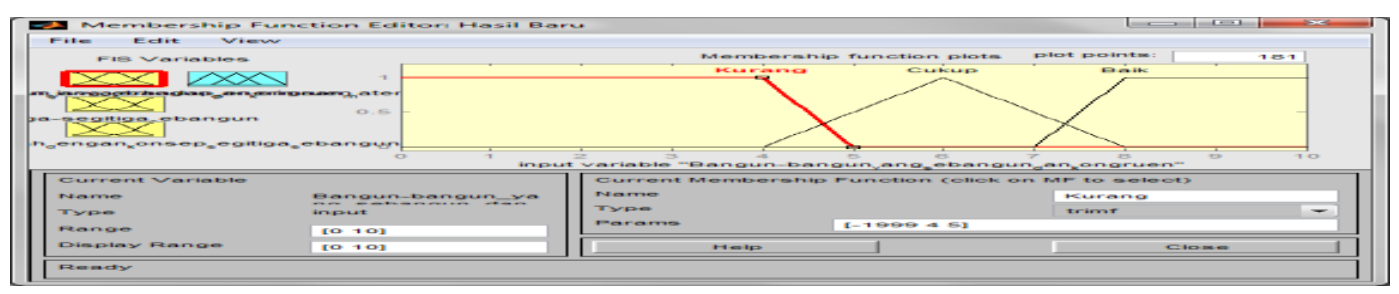


Gambar 7. Himpunan Fuzzy Input Bangun-bangun yang sebangun dan kongruen

b. Segitiga-segitiga sebangun

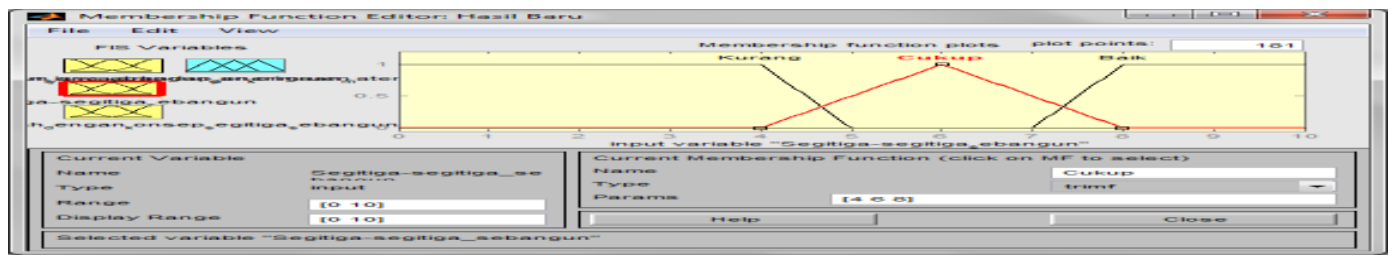

Gambar 8. Himpunan Fuzzy Input Segitiga-segitiga Sebangun

c. Pemecahan masalah dengan konsep segitiga sebangun

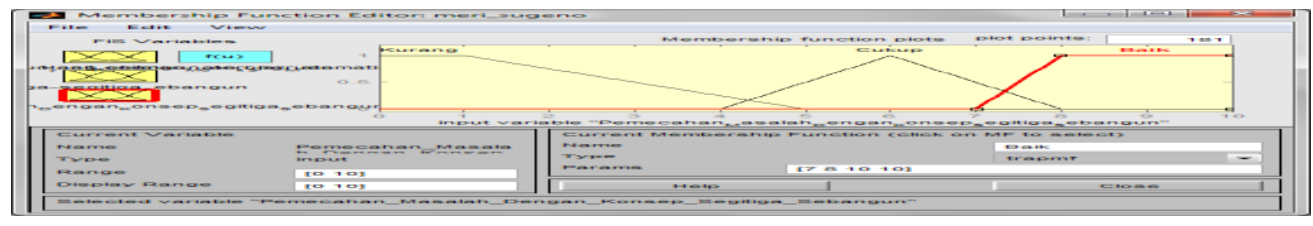

Gambar 9. Himpunan Fuzzy Input Pemecahan masalah dengan konsep segitiga sebangun

d. Hasil penilaian siswa terhadap materi ajar Matematika

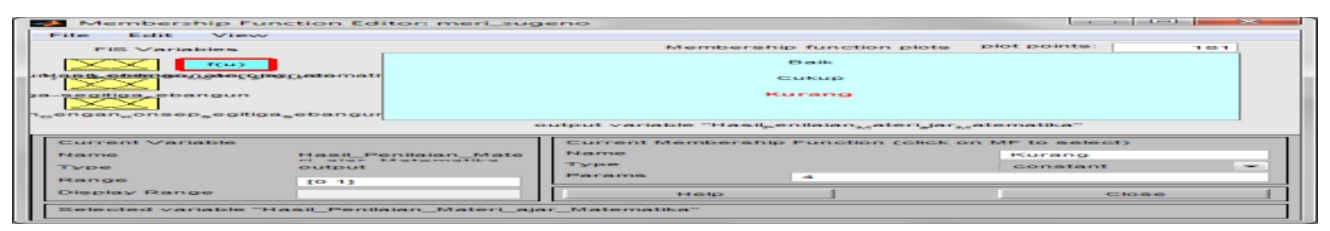

Gambar 10.Himpunan Fuzzy Output Hasil Penilaian siswa terhadap materi ajar Matematika

e. Rule

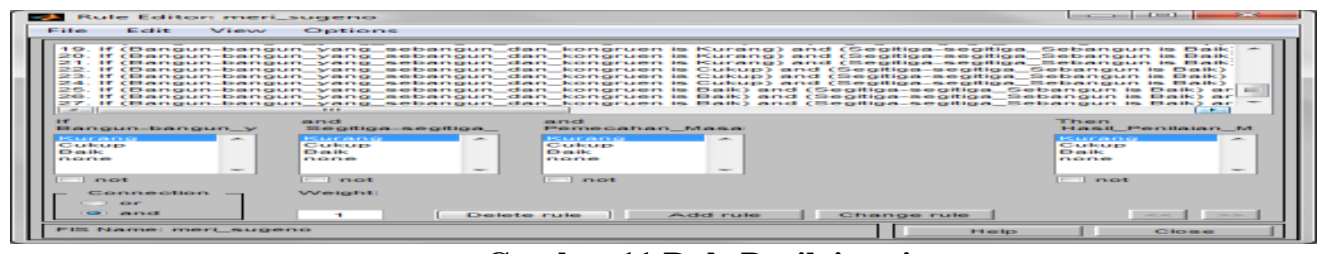

Gambar 11.Rule Penilaian siswa

f. Surface Viewer

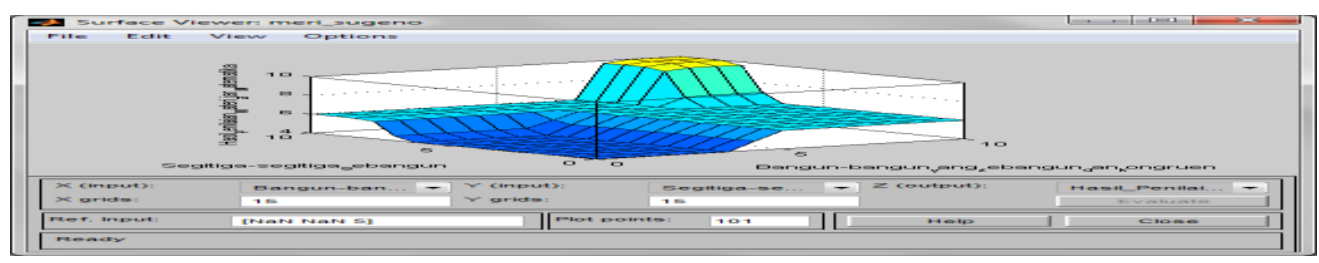

\section{Gambar I3. Surface Viewer Penilaian Siswa}

Inferensi/evaluasi rules

Setelah dilakukan fuzzyfikasi terhadap himpunan nilai, maka dibentuk rules untuk himpunan fuzzy tersebut. Rules diambil dari sampel data yang ada dan terbentuk 27rules.

\section{Graphical User Interface}

GUI dibuat menggunakan program Matlab R2012b.

Menggunakan aplikasi berbasis logika fuzzy terhadap penilaian siswa materi ajar Metode Mamdani. 


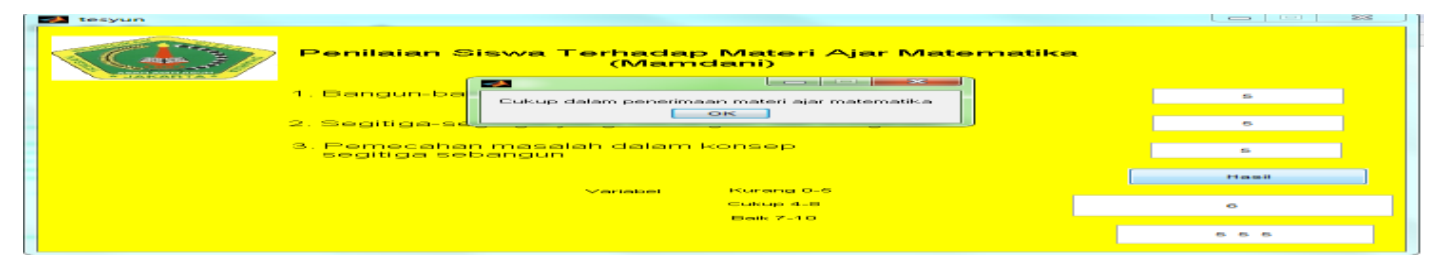

Gambar 12.GUI Penilaian Siswa Terhadap Materi Ajar Matematika Metode Mamdani

\section{Hasil Pengujian Prototipe Perangkat Lunak}

Tabel 3. Hasil Metric of Software Quality Assurance (SQA)

\begin{tabular}{|c|c|c|c|c|c|c|c|c|c|}
\hline \multirow{2}{*}{ User } & \multicolumn{8}{|c|}{ Skor Metrik } & \multirow{2}{*}{ Skor } \\
\hline & 1 & 2 & 3 & 4 & 5 & 6 & 7 & 8 & \\
\hline$\# 1$ & 79 & 80 & 79 & 81 & 82 & 77 & 78 & 80 & 79.35 \\
\hline$\# 2$ & 81 & 85 & 80 & 87 & 83 & 84 & 81 & 84 & 83.2 \\
\hline$\# 3$ & 87 & 82 & 81 & 84 & 87 & 85 & 82 & 84 & 83.85 \\
\hline \#4 & 80 & 84 & 83 & 90 & 90 & 81 & 83 & 85 & 84.25 \\
\hline$\# 5$ & 85 & 80 & 80 & 84 & 85 & 79 & 80 & 82 & 81.55 \\
\hline \multicolumn{9}{|c|}{ Rata-Rata } & 82.44 \\
\hline
\end{tabular}

Berdasarkan tabel di atas maka dapat diketahui bahwa dari 5 responden dengan 8 variabel penelitian, 4 diantaranya memperoleh nilai baik dan 1 responden penelitian memperoleh nilai cukup. Jika demikian maka secara umum aplikasi ini memiliki kualitas baik sehingga layak digunakan sebagai perangkat lunak untuk penilaian siswa terhadap materi ajar Matematika.

\section{Simpulan Dan Saran \\ Kesimpulan}

Berdasarkan analisis dan hasil pengujian yang telah dilakukan, maka dapat ditarik kesimpulan sebagai berikut:

1. Dengan Prototipe yang dibuat ini, maka penilaiansiswa terhadap materi ajar Matematika dapat lebih relevan dengan target-target yang sekolah berikan,

2. Dengan perbandingan metode yang digunakanuntukmenghitungpenilaian siswa terhadap materi ajar Matematika dapat memberikan alternative kepada Sekolah untuk memilih salah satu software. Alternatif ini langsung ditentukan olehSMP Citra Dharma sesuai dengan kebutuhan yang berlaku.

3. Berdasarkan pengujian dengan menggunakan metode SOA (Software Quality Assurance) system penilaian siswa terhadap penerimaan materi ajar Matematika telah memenuhi standar kualitas.

\section{Saran}

1. Perlunya mencoba metode fuzzy yang lain sebagai alternative solusi bagi SMP Citra Dharma.

2. Diperlukan penelitian lain menggunakan software selain Matlab untuk melihat kecepatan proses perhitungan hasil.

\section{Daftar Pustaka}

Cox, E. (1994).The Fuzzy System Handbook.(A Practitioner's Guide to Building, Using, and Maintaining Fuzzy System).Massachusetts, Academic Press.Inc.

Hamalik.(2006).Pendidikan Matematika . Jakarta: DEPDIKBUD.

Handayanto, Rahmadya Trias.(2009).Penerapan Soft Computing Dengan Matlab.Bandung : Rekayasa Sains.

Kusumadewi, S.(2002). Analisis \& Desain Sistem Fuzzy menggunakan Tool Box Matlab. Yogyakarta: Graha Ilmu. 
Matlab, Fuzzy Logic. Available at: http://www.mathworks.com/help/fuzzy/index.html [Accessed July 3, 2014]

Ruseffendi.(2006). Pendidikan Matematika. Jakarta: DEPDIKBUD.

R.S.Pressman.(2010). Software Engineering A Practitioner's Approach (7 ${ }^{\text {th }}$ ed.). New York: McGraw-Hill Companies, Inc.

Suharsimi.(2006). Dasar-dasarEvaluasiPendidikan. Jakarta: BinaAksara. 